\title{
Os princípios da boa-fé objetiva, da função social e da equivalência das prestações no novo Código Civil: uma (re)leitura do contrato
}

\author{
Luciane Maria Padoin*
}

"É o conhecimento dos princípios e a habilitação para manejá-los, que distingue o jurista do mero conhecedor de textos legais"1

\section{CONSIDERAÇÕES INICIAIS}

A evolução da sociedade trouxe, como um dos reflexos mais importantes, a modificação do papel do Estado frente aos cidadãos. O Estado Liberal, com sua característica de não interferir nas relações intersubjetivas, incapaz de resolver os problemas sociais, deu lugar ao Estado Social, isto é, um Estado que intervém no domínio privado, especialmente atingindo as relações contratuais.

Assim, uma grande marca da evolução da teoria contratual, em consonân- cia com a evolução da sociedade e a conseqüente transformação do Estado Liberal para o Social, foi o repensar dos princípios (liberais) norteadores das relações contratuais, em face do surgimento dos novos princípios, como: o da função social do contrato, da boa-fé objetiva, da probidade, e o da equivalência das prestações.

Em razão desse cenário traçado acima, perfilhou-se um novo caminho na teoria contratual, o qual necessita de reflexões, uma vez que o novo Código Civil, refletindo as características de um Estado Social, traz princípios que, até

\footnotetext{
* Especialista em Direito Imobiliário e Mestre em Direito pela Universidade de Santa Cruz do Sul - UNISC; Professora de Direito na UNISC e UFSM.

1 SUNFELD, Carlos Ari. In: ESPÍNDOLA, Ruy Samuel. Conceito de Princípios Constitucionais. 2 ed. São Paulo: Revista dos Tribunais, 2002. p. 13.
} 
então, fugiam das linhas traçadas pelo Código Civil anterior.

Por essas razões, nas linhas que se seguem, propõe-se refletir acerca de alguns desses novos princípios, sem, contudo, pretender esgotar o tema proposto, o qual necessita, pela sua abrangência e relevância, de estudos mais aprofundados e de maiores discussões.

\section{CONCEITO DE PRINCÍPIO JURÍDICO}

Inicialmente, cabe salientar que a palavra princípio não é utilizada exclusivamente no Direito, uma vez que é adotada em vários campos do saber humano, isto é, na Filosofia, na Teologia, na Sociologia, na Física e também no Direito - entre outras ciências. Porém, em cada campo assume um significado diferente. Embora haja essa amplitude, no presente estudo, revela-se importante (e interessa) tão somente verificar o conceito de princípio no campo do Direito, ou seja, os princípios jurídicos.

Para Ruy Samuel Espíndola, ${ }^{2}$ a idéia de princípio ou sua conceituação, seja lá qual for o campo do saber que se tenha em mente:

designa a estruturação de um sistema de idéias, pensamentos ou normas por uma idéia mestra, por um pensamento chave, por uma baliza normativa, donde todas as demais idéias, pensamentos ou normas derivam, se reconduzem e/ou se subordinam.

Assim, como expressa Elsita Collor Elesbão, ${ }^{3}$ princípios são

normas básicas, premissas. Critérios ou idéias fundamentais de um sistema jurídico determinado. Os princípios jurídicos não se caracterizam como algo fora do Direito, senão que, na expressão de Carnelutti, "están dentro del Derecho como el alcohol está en el vino".

Contudo, antes de encontrar a conceituação para princípios jurídicos, deve-se deixar bem claro que os princípios refletem o momento histórico. Para justificar essa afirmativa, volta-se aos princípios que nortearam o contrato na visão liberal: autonomia de vontade e pacta sunt servenda. Esses dois princípios, no século XIX, assumiam uma postura exclusivamente individualista, imperando na ordem contratual. Atualmente, tais princípios não apresentam a mesma definição, pois sofreram alterações, isto é, influências de novos princípios (como o da função social, boa-fé objetiva, eqüidade).

Norberto Bobbio, citado por Ruy Samuel Espíndola ${ }^{4}$ defende a idéia de que os princípios jurídicos são verdadeiras normas. Oportunamente, é de se lembrar que normas é gênero, cujas espécies são: as regras e os princípios. ${ }^{5}$

2 ESPÍNDOLA. Conceito de..., p. 53.

3 ELESBÃO, Elsita Collor. Princípios Informativos das Obrigações Contratuais Civis. Porto Alegre: Livraria do Advogado, 2000. p. 75-76.

4 ESPÍNDOLA. Conceito de... p. 62.

5 Espíndola aponta cinco critérios para diferenciar regras de princípio, a saber: a) O grau de abstração: os princípios são normas com um grau de abstração relativamente amplo; de modo 
Outra questão a ser apontada é a de que os princípios para existirem no ordenamento jurídico não necessitam estarem positivados. ${ }^{6}$ Para ratificar, basta lembrar do princípio que veda o enriquecimento sem causa (ou enriquecimento ilícito), pois, até o novo Código Civil, o mesmo não se encontrava expresso na lei, embora de forma implícita em alguns dispositivos, como é o caso do Dec. $n^{\circ} 22.626 / 33$ (conhecido como Lei da Usura).

É de se consignar que a idéia de normatividade não acompanhou sempre a concepção principiológica. Segundo Bonavides citado por Espíndola, ${ }^{7}$ a juridicidade ou a normatividade dos princípios passou por três distintas fases: a jusnaturalista, a positivista e a pós-positivista.

A primeira fase posiciona os princípios jurídicos em esfera abstrata e metafísica, pois, segundo Espíndola, ${ }^{8}$ são tidos como inspiradores de um ideal de justiça, cuja eficácia se cinge a uma dimensão ético-valorativa do Direito. Assim, a normatividade dos mesmos, se não for encarada como nula, ao menos era de duvidosa propriedade praxeológica. Essa corrente concebe os princípios gerais de Direito em forma de axiomas jurídicos ou normas estabelecidas pela reta razão. São, assim, normas universais de bem obrar. São princípios de justiça, constitutivos de um Direito ideal. São, em definitivo, um conjunto de verdades objetivas derivadas da lei divina e humana.

Na segunda fase, a juspositivista, os princípios, conforme Espíndola, ${ }^{9}$ entram nos códigos como fonte normativa subsidiária da inteireza dos textos legais. São encarados como válvulas de segurança que garantem o reinado absoluto da lei. Não são encarados como superiores às leis, mas delas deduzidos, para suprirem os vazios normativos que elas não puderem prever, isto é, são tidos como fontes

diverso, as regras possuem uma abstração relativamente reduzida. b) O grau de determinabilidade na aplicação do caso concreto: os princípios, por serem vagos e indeterminados, carecem de mediações (do legislador? do juiz?), enquanto as regras são susceptíveis de aplicação direta. c) Caráter de fundamentalidade no sistema de fontes de direito: os princípios são normas de natureza ou com papel fundamental no ordenamento jurídico devido à sua posição hierárquica no sistema das fontes (ex: princípios constitucionais) ou à sua importância estruturante dentro do sistema jurídico (ex: princípio do Estado de Direito). d) Proximidade da idéia de direito: os princípios são standards juridicamente vinculantes radicados nas exigências de justiça (Dworkin) ou na idéia de direito (Larenz); as regras podem ser normas vinculantes com um conteúdo meramente formal. e) Natureza normogenética: os princípios são fundamento de regras, isto é, são normas que estão na base ou constituem a ratio de regras jurídicas, desempenhando, por isso, uma função normogenética fundamentante. (ESPÍNDOLA, Conceito de... p. 70).

6 Karl Larenz destaca que os princípios não positivados irrompem no pensamento jurídico pelo umbral da consciência, devido a um caso pragmático. (LARENZ, Karl. Metodologia da Ciência do Direito. Lisboa: Calouste, 1997. p. 599).

7 ESPÍNDOLA, op. cit. p. 63.

8 Ibidem, p. 63.

9 Ibidem, p. 63. 
de integração do direito. $\mathrm{O}$ valor dos princípios está no fato de derivarem das leis, e não de um ideal de justiça.

A terceira e última fase, a do pós-positivismo, é inaugurada, como aponta o autor citado acima, ${ }^{10}$ nas últimas décadas, com a hegemonia axiológica-normativa dos princípios, que agora positivados nos novos textos constitucionais, assentam os principais padrões pelos quais se investiga a compatibilidade da ordem jurídica aos princípios fundamentais de escalão constitucional; aos princípios que dão fundamento axiológico e normativo ao ordenamento jurídico. Nesta fase, os princípios jurídicos conquistam a dignidade de normas jurídicas vinculantes, ${ }^{11}$ vigen- tes e eficazes para mera aplicação integratória do Direito.

O status de normatividade atribuído aos princípios, referido acima, decorre dos reflexos do Estado Social, onde se detecta uma postura intervencionista estatal, através, principalmente, da via legislativa. ${ }^{12}$ Nesse sentido, os princípios representam uma forma de tutelar, de modo abrangente, as relações sociais que nascem na sociedade, sem ficar presos à casuística. Em outras palavras, os princípios, tidos como normas, nascem da necessidade do Estado alcançar, juridicamente, todas as situações sociais, que surgem de formas céleres e imprevistas na atual sociedade (complexa e de massa) ${ }^{13}$

\section{ESPÍNDOLA. Conceito de..., p. 64.}

11 A positivação dos princípios, explicita Espíndola, ocorreu não só ao valioso trabalho teórico de juristas como Ronald Dworkin, mas também aos trabalhos de publicistas alemães, espanhóis e italianos, destacando-se o nome do alemão Robert Alexy. (Ibidem, p. 64)

12 Essa atitude intervencionista do Estado é chamada de dirigismo contratual. Nesse sentido, Gustavo Tepedino refere que: O Poder Público persegue certas metas, desenvolve nesta direção programas assistenciais, intervém conspicuamente na economia, vale-se de dirigismo contratual acentuado. O legislador trabalha freneticamente para atender à demanda setorial crescente, fala-se mesmo em uma "orgia legiferante". Configura-se, assim, de um lado, o direito comum, disciplinando pelo Código que regula, sob a velha ótica subjetivista, as situações jurídicas em geral; e, de outro, o direito especial, cada vez mais relevante e robusto, que retrata a intervenção do legislador em uma nova realidade econômica e política. A intensificação desse processo intervensionista subtrai do Código Civil inteiros setores da atividade privada, mediante um conjunto de normas que não se limitam a regular aspectos especiais de certas matérias, disciplinando-as integralmente. O mecanismo é finalmente consagrado, no caso brasileiro, pelo texto constitucional de 5 de outubro de 1988, que inaugura uma nova fase e um novo papel para o Código Civil, a ser valorado e interpretado juntamente com inúmeros diplomas setoriais, cada um deles com vocação universalizante. [...] Dito diversamente, a Constituição de 1988 retrata uma opção legislativa concordatária, em favor de um Estado Social destinado a incidir, no que concerne às relações jurídicas privadas, sobre um direito civil repleto de leis especiais, chamadas de estatutos, que disciplinam exaustivamente inteiras matérias extraídas da incidência do Código Civil. O Estatuto da Criança e do Adolescente, o Código de Defesa do Consumidor, a Lei das Locações, já reproduzindo outras leis anteriores à Constituição, como o Estatuto da Terra, todos esses universos legislativos apresentam-se radicalmente diversos das legislações excepcional e especial de outrora. (TEPEDINO, 2001. p. 6-7. Temas de Direito Civil. 2.ed. Rio de Janeiro: Renovar, 2001).

13 Fábio S. de Andrade ressalva que a adoção de um sistema de princípios conduz a um código menor que abdique da ambição de representar a integridade do direito privado. De modo que o conjunto de princípios não serve para substituir o código, mas para integrá-lo e adaptá-lo a uma sociedade em transformação permanente. (ANDRADE, Fábio S. Da codificação: crônica de um conceito. Porto Alegre: Livraria do Advogado, 1997. p. 160). 
Como o objetivo principal deste estudo é verificar alguns dos novos princípios que norteiam as relações contratuais, a seguir serão vistos os princípios da função social, da boa-fé objetiva, da probidade e o da equivalência das prestações.

\section{PRINCÍPIO DA FUNÇÃO SOCIAL}

A partir desse princípio, o contrato deixa para trás aquela visão individualista, passando a assumir uma postura social. Comentando sobre esse princípio, Cláudia Lima Marques ${ }^{14}$ aduz que:

o contrato não pode mais ser considerado somente como um campo livre e exclusivo para a vontade criadora dos indivíduos. Hoje, a função social do contrato, como instrumento basilar para o movimento das riquezas e para a realização dos legítimos interesses dos indivíduos, exige que o contrato siga um regramento legal rigoroso. A nova teoria contratual fornecerá o embasamento teórico para a edição de normas cogentes, que traçarão o novo conceito e os novos limites da autonomia da vontade, com o fim de assegurar que o contrato cumpra a sua nova função social. Nesse sentido, o Código de Defesa do Consumidor representa o mais novo e mais amplo grupo de normas cogentes, editado com o fim de disciplinar as relações contratuais entre fornecedor e consumidor, segundo os postulados da nova teoria contratual.

Assim, o novo Código Civil, sob inspiração da atual Constituição, traz em seu texto o princípio da função social do contrato, sob a forma de cláusula geral, ${ }^{15}$ no artigo 421, dispondo que a liberdade de contratar será exercida em razão e nos limites da função social do contrato.

Pela leitura do artigo supramencionado, observa-se que o novo Código não aboliu o princípio da autonomia das partes (liberdade de contratar), mas, sim, limitou-o ao cumprimento da função social.

Importa destacar que a concepção clássica do contrato, ${ }^{16}$ que era baseado

14 MARQueS, Cláudia Lima. Contrtos no Código de Defesa do Consumidor. 2.ed. São Paulo: Revista dos Tribunais, 1995. p. 90.

15 Para Karl ENGISH, cláusula geral é uma formulação da hipótese legal que, em termos de grande generalidade, abrange e submete a tratamento jurídico todo um domínio de casos. A técnica legislativa de cláusula geral contrapõe-se à técnica da tipificação ou casuística. Ainda Engish alerta que graças à generalidade das cláusulas gerais é possível sujeitar um mais vasto grupo de situações, de modo ilacunar e com possibilidade de ajustamento, a uma conseqüência jurídica. O casuísmo está sempre exposto ao risco de apenas fragmentária e provisoriamente dominar a matéria jurídica. Este risco é evitado pela utilização das cláusulas gerais. (ENGISH, Karl. Introdução ao Pensamento Jurídico. 6.ed. Lisboa: Calouste,1983. p. 233).

16 John GILISEN refere que a idéia de liberdade contratual é baseada em duas fórmulas: a primeira no laissez faire, laissez passer (deixai fazer, deixai passar) e a segunda na lei da oferta e da procura. O século XVIII significa a idade de ouro da liberdade absoluta das convenções entre vendedores e compradores, entre patrões e operários, entre senhorios e inquilinos, etc., com a consequiência da obrigação de as executar, mesmo se elas se revelassem injustas ou socialmente graves ou perigosas, posto que imperava o que fora pactuado livremente era justo. (GILISEN, John. Introdução Histórica ao Direito. 3.ed. Lisboa: Calouste, 2001. p. 738-739). 
do na vontade mútua das partes, prevalecendo o que elas pactuavam, não encontra mais espaço na atual sociedade; posto que o contrato assume, como já dito, uma visão (postura) social. Nesse aspecto, Mônica Yoshizato Bierwagen ${ }^{17}$ refere que:

a concepção clássica do contrato [...], cujo intuito não era precipuamente o de lucro, mas o de conservação (aquisição e disposição) da propriedade, demonstrava-se suficiente para a satisfação das expectativas de cada um dos contratantes, estando as partes em pé de igualdade, os contratos eram previamente negociados e celebrados com base no consenso mútuo. Tal esquema, contudo, demonstrou-se insuficiente para reger as relações negociais surgidas após a segunda metade do século XIX, quando se estabeleceu uma nova dinâmica negocial baseada no lucro; a partir de então avolumaram-se os contratos por conta da necessidade de se estabelecer o maior número de negócios possível; a paridade entre os indivíduos, que assegurava a expressão livre da vontade, foi substituída pela imposição do conteúdo dos contratos pelos grandes capitalistas; o equilíbrio social foi minado pela desmedida exploração do mais fraco. Isso, em última instância, significou o exercício ilimitado e irrestrito do direito de propriedade, que se viabilizava através dos contratos.
Oportunamente, ressalta-se que o contrato é compreendido como instrumento que viabiliza a circulação da riqueza, o qual deve ser vislumbrado sob dois prismas: do interesse particular (individual) e do interesse coletivo (público).

No que pertine ao interesse individual, ter-se-á cumprida a função social desde que o contrato não atente contra a liberdade e igualdade dos contratantes. Como bem afirma Bierwagen, ${ }^{18}$ quando entre os contratantes ocorre o desequilíbrio desses pressupostos (liberdade e igualdade), não há mais que falar em consenso, mas em imposição da vontade de uma parte à outra, e o contrato, que deveria representar a satisfação de um interesse para a que está em situação inferior, passa a ser apenas o atendimento de uma necessidade irrecusável.

Quanto ao interesse coletivo atentase ao fato de que o contrato também deve atender aos interesses que ultrapassam os interesses individuais das partes, quais sejam: os interesses sociais. ${ }^{19}$ Assim, caracterizaria ofensa ao direito coletivo um contrato de locação de um terreno, localizado na zona urbana de um município, entre uma pessoa física e uma particular que tem por objeto o armazenamento de lixo hospitalar sem o devido tratamento.

17 BIERWAGEN, Mônica Yoshizato. Princípios e Regras dos Contratos no Novo Código Civil. São Paulo, 2002. p. 40.

18 Ibidem, p. 41.

19 Os interesses sociais podem ser de três categorias: difusos, coletivos e individuais homogêneos. Em breve exposição, pode-se dizer que os interesses ou direitos difusos são aqueles que transindividuais e indivisíveis, titularizados por pessoas indeterminadas e ligadas por circunstâncias fáticas; como por exemplo: a colocação no mercado de produtos perigosos à saúde, a tutela ao meio ambiente. Já os interesses ou direitos coletivos referem-se aos transin- 
Embora possa o contrato de locação firmado entre as partes atender aos interesses entre locador e locatário, é de se observar que não atende aos interesses sociais, posto que há uma nítida ofensa ao meio ambiente, além de causar possíveis danos à saúde dos moradores próximos e de outros.

Resumindo esses dois aspectos em que a função social do contrato atinge, como bern refere Bierwagen, ${ }^{20}$ pode-se dizer que o contrato deve observar tanto a ótica individual-coletiva, uma vez que a garantia de igualdade de condições aos contratantes ao permitir a justa circulação de riquezas resulta num bem-estar coletivo, quanto da ótica coletivo-individual, em que a proteção do grupo social é, em última instância, o asseguramento da igualdade e da liberdade individuais.

Quanto ao reflexo decorrente da inobservância desse princípio, Paulo Na$\operatorname{lin}^{21}$ defende a nulidade do negócio contratual, afirmando que:

a nulidade será a sanção mais adequada ao quadro em questão, pois, na lição de PERLINGIERI, o regime de nulidade parte de um prisma de intensidades sancionárias variadas, sendo a nulidade a mais grave e, a anulabilidade, a menos grave. A nulidade se dirige à salvaguar- da de valores superiores, tutelando interesses gerais, ao passo que a anulabilidade se dirige à proteção dos interesses individuais das partes.

Chegando-se ao entedimento da nulidade, surge a dúvida de qual dispositivo fundamenta essa sanção. É certo que o ordenamento jurídico civilista considera nulo somente o negócio jurídico quando configurar uma (ou mais de uma) das hipóteses elencadas no artigo 166 do Código Civil atual. Sendo claro nesse artigo, no inciso VII, que será nulo quando a lei taxativamente o declarar nulo. Por isso, torna-se relevante discutir-se acerca da resposta a ser formulada quanto à fundamentação da nulidade, posto que há o predomínio do dogma da nulidade textual e não há, nos textos positivos pertinentes ao tema (Código Civil e Constituição Federal), disposição em torno da nulidade por infringência ao princípio.

Como não existe um artigo específico informando sobre a nulidade, a doutrina tem entendido que, nesses casos, incide a chamada nulidade virtual.

Paulo Nalin ${ }^{22}$ afirma que a doutrina brasileira pouco se refere ao tema da nulidade virtual, contextualizando-a mediante critérios nada específicos do sistema positivo. Isso decorre do dog-

dividuais, titularizados por grupo, categoria ou classe, que são determinados seja pela relação jurídica base que os une, seja através de vínculo jurídico que os liga com a parte contrária; como exemplo: estudantes de uma mesma universidade. E, por fim, os direitos ou interesses individuais homogêneos são aqueles que têm origem comum, não transcendem a figura do indivíduo e são divisíveis, como por exemplo: os consumidores de um determinado produto contendo substância nociva à saúde.

20 BIERWNGER. Princípios e... p. 45.

21 NALIN, Paulo. Do Contrato: Conceito Pós-Moderno. Curitiba: Juruá, 2001. p. 237.

22 GOMES, Orlando apud NALIN. Do Contrato... p. 238. 
matismo da nulidade textual, caprichosamente prevista, hoje, no artigo 166, inciso VII, do CC, na qual negócio jurídico nulo é aquele praticado com infração de preceito legal de ordem pública ou de norma imperativa.

Orlando Gomes citado por Paulo Nalin, ${ }^{23}$ ao contrapor a nulidade virtual com a textual, deduzindo ser ela implícita, decorrente da função da norma jurídica e não de texto sancionário expresso, reconhece a dificuldade de sua determinação, na falta de texto legal ou critério geral que a sustente. Da mesma forma, Francisco Amaral citado por Nalin, ${ }^{24}$ conclui ser a nulidade virtual tácita, pois que não expressa, dedutível das normas ou dos princípios jurídicos.

Em exposição final, Nalin ${ }^{25}$ entende que se revela adequada uma adoção mais prática e efetiva da nulidade virtual,

pois inexiste a previsão sancionatória, quando não cumprir o contrato a sua função social. E assim se mostra oportuna a nulidade virtual, seja porque de ordem pública as regras pertinentes ao tema, tanto na esfera constitucional quanto na ordinária, seja porque inderrogáveis absolutas, seja porque encerram uma tutela que supera o mero fato do contratante mais débil (técnico, fático ou jurídico), mas sobretudo em razão de sua função mais justa. O segundo aspecto, de cunho mais positivo, mostra que no âmbito do próprio Código Civil de 1916 localiza-se o fundamento da nulidade virtual, con- forme prevê o seu artigo 145 , inc. II, ${ }^{26}$ pois um contrato desprendido de sua função social sempre trará consigo um objeto ilícito, uma vez que contraria a ordem jurídica e a finalidade constitucional, de modo a eivá-lo de nulidade, mesmo que não prevista a sanção.

Parece que, realmente, essa é a interpretação mais adequada, uma vez que, se não pudesse nulificar um contrato que não atenda à função social, restaria letra morta o artigo 421 do Código Civil.

Ainda oportuno se considerar que a nulidade pode atingir todo o contrato, como no exemplo exposto acima (da locação do terreno para armazenamento de lixo tóxico), como também pode atingir alguma cláusula contratual. Nesse caso, é lícito à parte prejudicada ingressar com uma demanda, requerendo a declaração da nulidade da cláusula e, conseqüentemente, que o juiz integre o contrato de forma a (re)estabelecer a harmonia contratual.

\section{PRINCÍPIO DA BOA-FÉ OBJETIVA E O PRINCÍPIO DA PROBIDADE}

O princípio da boa-fé biparte-se em boafé subjetiva e objetiva. Por isso, antes de fazer alusão ao princípio da boa-fé objetiva, é importante traçar a distinção entre a boa-fé subjetiva e a boa-fé objetiva.

Tal distinção é buscada nas palavras de Judith Martins-Costa: ${ }^{27}$

23 AMARAL, Francisco apud NALIN, op. cit. p. 238-239.

24 Ibidem, p. 239.

25 Ibidem, p. 242.

26 No Novo Código é o artigo 166, inc. VII.

27 MARTINS-COSTA, Judith. A Boa-Fé no Direito Privado. São Paulo: Revista dos Tribunais, 2000. p. 411-412. 
a expressão boa-fé subjetiva denota estado de consciência, ou convencimento individual de obrar [a parte] em conformidade ao direito [sendo] aplicável, em regra, ao campo dos direitos reais especialmente em matéria possessória. Dizse subjetiva justamente porque, para sua aplicação, deve o intérprete considerar a intenção do sujeito da relação jurídica, o seu estado psicológico ou íntima convicção. Antitética à boa-fé subjetiva está a má-fé, também vista subjetivamente como a intenção de lesar outrem. Já por boa-fé se quer significar - segundo a conotação que adveio da interpretação conferida ao $\$ 242$ do Código Civil Alemão, de larga força expansionista em outros ordenamentos, e, bem assim, daquela que lhe é atribuída nos países da cammon law - modelo de conduta social, arquétipo ou stardard jurídico, segundo o qual cada pessoa deve ajustar a própria conduta a esse arquétipo, obrando como obraria um homem reto: com honestidade, lealdade, probidade. [...] ao conceito de boa-fé objetiva estão subjacentes as idéias e ideais que animaram a boa-fé germância: a boa-fé como regra de conduta fundada na honestidade, na retidão, na lealdade e, principalmente, na consideração para com os interesses do "alter", visto como um membro do conjunto social que é juridicamente tutelado. Aí se insere a consideração para com as expectativas legitimamente geradas pela própria conduta, nos demais membros da comunidade, especialmente no outro polo da relação obrigacional.

Oportunamente, mister considerar que a distinção clara entre boa-fé subjetiva e boa-fé objetiva veio do direito civil germânico, especificamente no Código Civil (BGB). Nesse sentido, Menezes Cordeiro ${ }^{28}$ alude que:

o BGB se refere à boa-fé objetiva (treu und glauben) em cinco das suas disposições e à boa-fé subjetiva em dezesseis disposições. Ainda acrescenta que dada a importância, quanto à boa-fé objetiva, mereceu esta destaque também em legislação extravagante, dispondo no § 9/ 1 do AGBG de 9 de dezembro de 1976: As disposições das condições negociais gerais são ineficazes quando desfavoreçam, contra a regra da boa-fé, de modo desmensurado, o parceiro contratual do aderido.

Embora tenha o BGB contraposto com clareza a boa-fé objetiva em relação à subjetiva, não quer dizer que a boa-fé teve origem nesse ordenamento. Em rápidas digressões, pode-se dizer que a boa-fé tem raízes no direito romano, assumindo, aí, implicações de ordem religiosa, ética e moral, sem ter uma preocupação de ordem jurídica.

A juridicização da boa-fé só veio a ocorrer, conforme Bruno Lewicki, ${ }^{29}$

com o incremento do comércio e o desenvolvimento do ius gentium, complexo jurídico aplicável a romanos e estrangeiros. [...] Esta noção, com traços da boa-fé objetiva da doutrina hodierna, foi bastante diluída no Corpus Iuris Civilis. Soma-se a isto a difusão, ainda antes da compilação justinianéia, da idéia da bona fides como um estado psicológico de ignorância que tornara-se um requisito para o usucapião;

28 CORDEIRO, Manuel António da Rocha e Menezes. Da Boa-Fé no Direito Civil. Coimbra: Almedina, 1997. p. 325-326.

29 LEWICKI, Bruno. Panorama da Boa-Fé Objetiva. In: TEPEDINO, Gustavo (coord.) Problemas de Direito Civil-Constitucional. Rio de Janeiro: Renovar, 2000. p.58-59. 
e ainda a influência do direito canônico, que via a boa-fé como "ausência de pecado", ligada principalmente ao fenômeno da prescrição. Estes fatores se sobrepõem durante o medievo, proporcionando um quadro de progressivo abandono do olhar objetivista sobre a boa-fé, cada vez mais identificada com a visão subjetiva.

Essa situação só veio a ser alterada com o Código Civil Francês (1804), que dispôs ern vários artigos sobre a boa-fé subjetiva, especialmente ligado ao direito possessório, e somente em um artigo (art. 1.134) há referência à boa-fé objetiva no que diz respeito aos efeitos das obrigações, dispondo que as convenções legalmente constituídas devem ser executadas de boa-fé.

Contudo, a disposição referente à boa-fé objetiva, nas palavras de Bruno Lewicki: ${ }^{30}$

acabou tornando-se letra morta para os juristas que foram responsáveis pelas primeiras interpretações do Code, influenciando uma série de seguidores e criando uma escola que dominaria a hermenêutica do oitocentos: a Exegese, caracterizada pelo apego imorredouro à letra da lei Napoleônica. Alguns fatores foram fundamentais para este desprezo que a escola da Exegese demonstraria pelo instituto da boa-fé objetiva, como a própria incongruência do artigo 1.134 , que, antes de aludir à lealdade contra- tual, estabeleceu que as convenções legalmente pactuadas têm força de lei entre as partes. Sobretudo, restringiuse o campo de atuação do princípio da boa-fé pela forma como ele foi positivado no Code, necessitando, para sua concreção, de uma maior abertura à atividade discricionária do julgador - o que, sem dúvida, era inconciliável com o método exegético.

É importante consignar que a jurisprudência alemã já vinha aplicando a boa-fé objetiva antes mesmo da da vigência do BGB, notadamente no direito comercial. Tal constatação é ratificada por Judith Martins-Costa, ${ }^{31}$ ao asseverar que a difusão da boa-fé objetiva, na sequência da entrada em vigor do BGB, é apenas aparente, uma vez que, representa uma continuidade de práticas judiciais assentes numa experiência extensa da jurisprudência comercial alemã.

Posteriormente, a boa-fé objetiva veio a se espalhar em outras legislações como o Código Civil Italiano (1942) e o Código Suíço (1907). No Brasil, isto é, no Código de 1916, não há menção expressa a esse princípio. ${ }^{32}$

O Código de 1916 contemplou a boafé, assim como o Código Napoleônico, conforme alega Roberto Sensi Lisboa ${ }^{33}$ disciplinando-a no que pertine aos di-

30 Ibidem, p. 60.

\section{MARTINS-COSTA. Da Boa-Fé. p. 209.}

32 Clóvis V. do Couto e Silva alega que, no direito pátrio, não existia dispositivo legislativo contemplando a boa-fé no direito obrigacional; contudo, sendo fundamental para esse ramo do direito, sua presença independe de sua recepção legislativa. Ressalva ainda o autor que o Código Comercial dispôs, no art. 131, I, esse princípio, incluindo-o no campo obrigacional e relacionou-o com os usos de tráfico (1976, p. 29-30).

33 LISBOA, Roberto Senise. Contratos Difusos e Coletivos. 2 ed. São Paulo: Revista dos Tribunais, 2000. p. 90-91. 
reitos possessórios e no mundo obrigacional e negocial. Neste último aponta, como exemplos, os artigos 933 , § único, 935, 986, 1.072, 1.272, 1.316, 1.318, $1.321,1.382,1.404,1.437,1.443$ a 1.446 e 1.454. O estatuto pátrio fixou, assim, várias disposições sobre a boafé subjetiva - ignorância ou não da posse indevida - e acerca da boa-fé objetiva - onde não se cogita a existência de tal erro absoluto, mas tão-somente de regra de conduta a ser seguida pelo indivíduo.

O novo Código Civil, alterando o panorama do Código anterior, contempla expressamente, através de uma cláusula geral, a boa-fé objetiva no artigo 422 , dispondo que os contratantes são obrigados a guardar, assim na conclusão do contrato, como em sua execução, os princípios de probidade e boafé. Quanto à boa-fé subjetiva, o novo Código continua reportando-a aos direitos possessórios.

É importante frisar, como bem aponta Bierwagen, ${ }^{34}$ que:

a grande novidade não é pois a "invenção" da boa-fé objetiva na sistemática do novo Código Civil, mas sim o seu reforço através de uma cláusula geral, de conteúdo propositadamente vago, no prólogo das normas de direito contratual, de forma a não ensejar quaisquer dúvidas de que os contratos hão de ser negociados, concluídos e executados com confiança, lealdade e retidão e que tais comportamentos, exatamente por abrigarem inumeráveis condutas possíveis, exigirão do intérprete, na busca da concreção daquele mandamento, a observação, caso a caso, desses mesmos elementos.

O Código de Defesa do Consumidor (1990), antes mesmo do novo Código Civil, já previa a boa-fé objetiva no artigo $4^{\circ}$, III e no art. 51, inc. IV. Essa última previsão legal constitui-se em uma verdadeira cláusula geral - cláusula geral da boa-fé -, permitindo ao juiz, a cada caso concreto, sem estar preso a uma casuística, proteger o consumidor, através da declaração de nulidade de disposições contratuais contrárias a essa regra de conduta.

A partir do CDC, pode-se afirmar que a teoria contratual encontra um novo rumo, sem descurar que esse Código é reflexo da Constituição Federal, que impôs uma nova ordem jurídica. Nesse sentido, Cláudia Lima Marques ${ }^{35}$ reflete que:

como novo paradigma para as relações contratuais de consumo de nossa sociedade massificada, despersonalizada e cada vez mais complexa, propõe a ciência do direito o renascimento ou a revitalização de um dos princípios gerais do direito [...]: o princípio geral da boa-fé. Este princípio ou novo "mandamento" obrigatório a todas as relações contratuais na sociedade moderna, e não só às relações de consumo, será aqui denominado de Princípio da Boa-Fé Objetiva [...].

A autora acima ${ }^{36}$ destaca ainda que o princípio da boa-fé objetiva, na for-

34 BIERWAGEN. Princípios e Regras... p. 51.

35 MARQUES. Contratos... p. 78-79.

36 Ibidem... p. 79. 
mação e na execução das obrigações, possui dupla função na nova teoria contratual, isto é uma como fonte de novos deveres especiais de conduta durante o vínculo contratual, os chamados deveres anexos, e outra como causa limitadora do exercício, antes lícito, hoje abusivo, dos direitos subjetivos.

Os deveres em anexo acompanham o contrato desde a fase pré-negocial, o momento da sua conclusão e após sua perfectibilização. Cláudia Lima Marques $^{37}$ refere como deveres anexos: o dever de informar, o dever de cooperação e o dever de cuido.

Quanto a esses deveres, a autora aci$\mathrm{ma}^{38}$ aponta que o primeiro (dever de informar) é verificado na fase pré-contratual, imputando-lhe tanto ao fornecedor de bens/serviços quanto ao consumidor. Esse dever de informar se desdobra, conforme a doutrina estrangeira, no dever de esclarecimento e de aconselhamento. O dever de esclarecimento refere sobre as informações do produto ou serviço, quanto a sua segurança, riscos, qualidade, forma de utilização, entre outros. O dever de aconselhamento é um dever mais forte e só existe nas relações entre um profissional especialista e um não especialista, como ocorre nos médicos que receitam determinado remédio, que aconselham o paciente a submeter-se a determinada cirurgia ou a determinado tratamento, a utilizar determinado hospital, deixando (ou omitindo) de informar as outras possibilidades ou outros possíveis caminhos, que, como especialistas, devem conhecer e informar. O segundo dever anexo, o de cooperação - implica em agirem as partes com lealdade e não obstruir ou impedir. Assim, por exemplo, quando o consumidor necessita adimplir a sua obrigação e o fornecedor dificulta o pagamento, ao determinar que este só pode ser executado em local especial ou horas difíceis. E o último dever - o de cuido - tem por fim preservar o co-contratante de danos à sua integridade pessoal (moral ou física) e de seu patrimônio.

No tocante à segunda função desse princípio - limitar os direitos subjeti$\operatorname{vos}^{39}$ - Aline Arquette Leite Novais ${ }^{40}$ destaca que limitar o exercício dos direitos subjetivos, nada mais expressa do que a obediência ao mandamento constitucional de que o contrato cumpra sua função social.

Por conseguinte, entende-se que essa segunda função é o acolhimento da visão coletivista do contrato, pois ele deve atender, além dos interesses e expectativas individuais das partes (contidos nos deveres anexos), aos interesses coletivos.

37 MARQUES. Contratos..., p. 82-83.

38 Ibidem, p. 83-87.

39 Clóvis V. do Couto e Silva aponta que a boa-fé norteia o vínculo obrigacional, ao determinar "o que" e "o como" da prestação, ficando o interesse de cada contratante limitado ao do outro, por isso, esse princípio é um mandamento de consideração (SILVA, Clóvis V. do Couto e. A Obrigação como Processo. São Paulo: Bushatasky, 1976. p. 30).

40 NOVAIS, Aline Arquette Leite. Breves Reflexões sobre a Eficácia atual da Boa-Fé Objetiva no Ordenamento Jurídico Brasileiro. In: TEPEDINO, Gustavo (Coord.). Problemas de Direito Civil. Rio de Janeiro: Renovar, 2001. p. 30. 
Reportando-se também aos deveres anexos, mas se referindo especificamente sobre esses como reflexos da cláusula geral da boa-fé esculpida no artigo 422, do novo Código Civil, Celso Marini $^{41}$ assevera que essa cláusula tem o condão ético de impor às partes o respeito e a lealdade recíprocos. De tal reconhecimento, tem-se que, em todos os contratos, existem deveres anexos, tais como os de: informar, assistência e sigilo. O dever de informar é aquele através do qual nenhuma característica do produto pode ser negligenciada. $\mathrm{O}$ dever de assistência importa em comando normativo entre as partes, ante o negócio jurídico realizado, visando a consecução e fins previstos no contrato (fases pré, na execução e pós contratual). $O$ dever de guardar sigilo em relação ao contratado decorre da premissa que os direitos da personalidade do contratante devem ser preservados.

Por direitos da personalidade do contratante, $o$ autor citado antes ${ }^{42}$ aduz que são aqueles ligados à imagem e à honra, e como exemplo de violação a esses direitos (e, consequientemente, ao dever do sigilo), expõe a situação fática de quando uma empresa vende seu banco de dados contendo o cadastro de seus clientes a outra empresa, que deles se utiliza para propor novos negócios.

Caso ocorra o descumprimento de um dos deveres anexos, conforme Cláudia Lima Marques, ${ }^{43}$ significa inadim- plemento contratual, mesmo que parcialmente.

Nesse inadimplemento não está inserida a exigibilidade da culpa, podendo a parte prejudicada ingressar com a respectiva demanda, buscando indenização pelos danos sofridos ou, então, recorrer à medida judicial cabível em cada caso concreto.

Pela exposição feita acima, não resta dúvida de que o princípio da boa-fé objetiva, juntamente com a função social, trouxe uma nova visão aos contratos, impondo aos contratantes um dever de conduta, que deve ser observado em todas as fases do contrato (inclusive a fase após a sua conclusão), a qual é refletida nos deveres anexos. Assim, valendo-se das palavras de Cláudia Lima Marques, ${ }^{44} \mathrm{o}$ princípio da boa-fé significa:

uma atuação refletida, uma atuação refletindo, pensando no outro, no parceiro contratual, respeitando-o, respeitando seus interesses legítimos, suas expectativas razoáveis, seus direitos, agindo com lealdade, sem abuso, sem obstrução, sem causar lesão ou desvantagem, cooperando para atingir o bom fim das obrigações: o cumprimento do objetivo contratual e a realização dos interesses das partes.

Como expresso no citado artigo 422 , além da boa-fé, os contratos devem atender à probidade.

O princípio da probidade é compreendido como um reforço ao princípio da

41 MARINI, Celso. Algumas Considerações Importantes sobre os Contratos . Disponível em <http://www.irib.org.br/be/be.asp> Acesso em: 05 mar. 2003.

42 MARINI. Considerações....

43 MARQUES. Contratos... p. 82.

44 Ibidem, p. 79-80. 
boa-fé. Nesse mesmo raciocínio, Bierwagen ${ }^{45}$ remete:

que a probidade, quando entendida como a honestidade de proceder ou a maneira criteriosa de cumprir todos os deveres, que são atribuídos ou cometidos à pessoa, nada mais é senão um dos aspectos objetivos do princípio da boa-fé. Nesse sentido, aliás, é válido mencionar as palavras de Alípio Silveira: A boa-fé objetiva pode ser definida, na esfera jurídica, como comportamento inspirado no senso da probidade, quer no exercício leal e não caviloso dos direitos e das obrigações que dele derivam, quer no modo de fazê-los valer e de observá-los, respeitando, em qualquer caso o escopo visado pelo ato jurídico, a harmonia dos interesses das partes e as exigências do bem comum.

Por derradeiro, a disposição desses dois princípios num único artigo (art. 422), leva a acatar a idéia de que ambos convergem e reforçam a exigência de um comportamento contratual no sentido de atingir os fins principais do negócio: o cumprimento das obrigações e, conseqüentemente, a satisfação dos interesses das partes; lembrando que o comportamento contratual exigido pelo Código atinge todas as fases contratuais.

\section{PRINCÍPIO DA EQUIVALÊNCIA DAS PRESTAÇÕES}

O princípio da equivalência das prestações busca preservar o equilíbrio entre os direitos e deveres das partes contratantes; eis que, durante a execução do contrato, poderão ocorrer circunstâncias que alterem o panorama verificado no momento da conclusão do contrato, tornando a prestação de uma das partes excessivamente onerosa, rompendo assim o equilíbrio das prestações assumidas no contrato.

A partir da afirmativa acima, chegase ao entendimento de que esse princípio somente é verificado quando se tratar de contrato cujas prestações se protraem no tempo. Em outras palavras, somente quando se tratar de contrato comutativo e de execução diferida (ou trato sucessivo) ou de execução continuada, não incidindo quando se tratar de contrato de execução instantânea. ${ }^{46}$

Esse princípio tem sua essência articulada à teoria da imprevisão (antiga cláusula rebus sic stabntibus), a qual, após a Primeira Guerra Mundial, quando o Estado começa a intervir na esfera privada, começou a tomar forças. ${ }^{47}$

Com efeito, no Estado Liberal, a aplicação da cláusula rebus sic stantibus

45 BIERWAGEN. Princípios e regras... p. 49

46 Contrato de execução diferida é aquele em que as prestações, dada a natureza do negócio, se estendem no tempo, como ocorre no contrato de locação de imóvel residencial, seguro, compra e venda a prazo; enquanto o contrato de execução continuada é aquele realizável em um só ato, sendo que as partes adiam o cumprimento de suas obrigações para um momento posterior à conclusão do negócio, como ocorre na compra e venda cuja entrega da coisa ocorrerá três meses após. Muitos doutrinadores, como Sílvio Rodrigues e Maria Helena Diniz, classificam os contratos como instantâneos e de execução diferida no futuro, ou como de execução imediata e continuada, não fazendo a diferenciação das espécies execução continuada e diferida.

47 Ratificando o ressurgimento da cláusula, Osvaldo de Carvalho Monteiro, comentando, em um artigo escrito em 1943, portanto, ainda sob fortes efeitos do período de guerra, sobre a 
não tinha espaço, uma vez que não havia possibilidade de discussão judicial acerca da desproporcionalidade entre as prestações dos contraentes, posto que o contrato fazia lei entre as partes e, por isso, deveria ser plenamente cumprido.

Embora, antes da vigência da atual Constituição Federal, a doutrina e a jurisprudência brasileiras vinham reconhecendo a possibilidade da revisão contratual com base na cláusula rebus sic stantibus ou teoria da imprevisão.

Notadamente, após a vigência da Carta Magna, em 1988, através do princípio da isonomia (art. $5^{\circ}$ ) e da defesa do consumidor (art. $5^{\circ}$, XXXII e art. $170, \mathrm{~V})$, aliada ainda a uma postura interventiva do Estado, a cláusula rebus sic stantibus ganhou forças, vindo a ser adotada pelo novo Código Civil, nos $\operatorname{artigos} 478$ a 480.
É certo que, antes do novo Código Civil, a Lei 8.078/90, também fruto do contexto jurídico-social, trouxe às relações de consumo a possibilidade de revisar o contrato, ao dispor, no artigo $6^{\circ}, \mathrm{V}$, o direito básico do consumidor a modificação das cláusulas contratuais que estabeleçam prestações desproporcionais ou sua revisão em razão de fatos supervenientes que as tornem excessivamente onerosas.

Quanto a esse artigo, a doutrina diverge se houve a adoção ou não da teoria da imprevisão ou cláusula rebus sic stantibus. Tal dúvida reside no fato de que a teoria da imprevisão exige, para sua aplicação, a ocorrência de acontecimentos supervenientes após a conclusão do contrato e que os mesmos sejam imprevisíveis e extraordinários, causando para uma das partes onerosidade excessiva e extrema vantagem para a outra.

aplicação da teoria da imprevisão no direito inglês, após a primeira Grande Guerra, utiliza um trecho de uma publicação daquele país, onde se constata o seguinte: "A imensa deslocação dos negócios produzidos pela grande guerra induziu, ou trouxe à luz, um outro desenvolvimento da doutrina que uma radical mudança de circunstâncias pode libertar um contratante de suas obrigações. Esse novo desenvolvimento é conhecido como a doutrina frustration of adventure. Quando, por exemplo, um contrato celebrado antes da guerra teve, por efeito da guerra, o cumprimento tornado ilícito, fisicamente impossível, ou exeqüível somente com um prejuízo ruinoso do devedor, as Cortes, em circunstâncias não muito bem definidas, exoneraram o devedor do cumprimento dessas obrigações. É uma extensão da doutrina de rebus sic stantibus, que se entendeu governar a aplicação dos tratados internacionais. É uma doutrina perigosa, mas quase inevitável em certos tempos." (MONTEIRO, Osvaldo de Carvalho. Cláusula Rebus Sic Standibus. Revista Forense, Rio de Janeiro, v.49, n. 476, p. 242-255, abr.1943 p. 243).

$\mathrm{O}$ artigo inglês, mencionado pelo autor citado no parágrafo anterior, reflete o pensamento pós-guerra, uma vez que fora escrito no afã desse período. É interessante observar, no final do texto, a afirmação de que a teoria da imprevisão é uma doutrina perigosa, mas quase inevitável em certos tempos. Tal afirmativa decorre do choque entre a lei - no caso o princípio da obrigatoriedade dos pactos - e a realidade. Em outras palavras, a imutabilidade dos contratos não correspondia mais à realidade na qual se apresentava. O período pós-guèrra alterou a economia dos países europeus, o que implicou na necessidade dos contratos serem revistos para adaptar-se à nova situação econômica; tornando-se, assim, inevitável a aceitação dessa teoria, embora perigosa, não havia outra solução. 
Entendendo que o referido artigo não adota a teoria da imprevisão, Fabiana Rodrigues Barletta ${ }^{48}$ expõe que:

a revisão contratual positivada no artigo objeto desta análise visa a restaurar o equilíbrio do contrato e tornar possível o alcance de sua finalidade objetiva. Neste sentido, este dispositivo recebeu influências da teoria da quebra da base objetiva de Larenz, avançando ainda mais por desconsiderar por completo a previsibilidade ou a imprevisibilidade das transformações, firmando-se, pois, no requisito objetivo da excessiva onerosidade superveniente. Por esta razão, pode-se dizer que o dispositivo em pauta contém positivada a "teoria da onerosidade excessiva".

Também segue a mesma linha de raciocínio, Cláudia Lima Marques, ${ }^{49}$ ao comentar que a norma do art. $6^{\circ}$ do CDC

avança ao não exigir que o fato seja superveniente ou irresistível, apenas exige a quebra da base objetiva do negócio, a quebra de seu equilíbrio intrínseco, a destruição da relação de equivalência entre prestações, ao desaparecimento do fim essencial do contrato. Em outras palavras, o elemento autorizador da ação modificadora do Judiciário é o resultado objetivo da engenharia contratual, que agora apresenta a mencionada onerosidade excessiva para o consumidor, resultado de simples fato superveniente.
Realmente, dizer-se que o artigo $6^{\circ}$, inciso $\mathrm{V}$, do CDC adotou a teoria da imprevisão seria ir de encontro ao sistema protetivo que envolve a figura do consumidor, pois seria exigir-lhe provas muito difíceis a serem produzidas - isto é, provas de cunho subjetivo quanto à previsibilidade e extraordinalidade. Por conseguinte, é de entender que tal dispositivo abriga a Teoria da Base Objetiva do negócio, sendo necessário auferir a excessiva onerosidade superveniente.

De forma diversa, o novo Código Civil, como já mencionado, adotou a teoria da imprevisão, ainda que questionável em alguns aspectos.

Para relembrar as conseqüências jurídicas advindas de tal teoria, pode-se dizer que a mesma proporciona: o desfazimento ou a revisão, via judicial, do contrato, desde que a prestação de uma das partes tenha se tornado excessivamente onerosa em face de fato imprevisível e extraordinário, recebendo a outra parte extrema vantagem.

É importante se frisar bem essas conseqüências: revisão ou desfazimento do contrato, uma vez que o novo Código Civil deixa margens de dúvida quanto às mesmas. Para detectar tal dúvida, basta rever o art. 478 que refere:

nos contratos de execução continuada ou diferida, se a prestação de uma das partes se tornar excessivamente onerosa,

48 BARLETTA, Fabiana Rodrigues. A Revisão Contratual por Excessiva Onerosidade Superveniente à Contratação Positivada no Código de Defesa do Consumidor sob a Perspectiva Civil-Constitucional. In: TEPEDINO, Gustavo (coord). Problemas de Direito Civil-Constitucional. Rio de Janeiro: Renovar, 2000. p. 300.

49 MARQUES. Contratos... p. 299. 
com extrema vantagem para a outra, em virtude acontecimentos extraordinários e imprevisíveis, poderá o devedor pedir a resolução do contrato.

A partir desse dispositivo, pode-se extrair os seguintes requisitos, considerando-se que o artigo só prevê a possibilidade de resolução contratual: a) contrato de execução continuada ou diferida; b) a prestação de uma das partes torna-se excessivamente onerosa; c) e a prestação da outra extremamente vantajosa; e d) ocorrência da superveniência de acontecimentos extraordinários e imprevisíveis.

Antes de serem tecidos comentários acerca dos aludidos requisitos, mister se faz levantar a seguinte questão: o artigo 478, ao não prever a possibilidade de revisão contratual, excluiu-a?

Como o cerne da teoria da imprevisão é possibilitar a revisão ou a resolução contratual, não parece que o dispositivo ora mencionado teve o condão de excluir a primeira hipótese. Ainda mais considerando que, se é possível a resolução, que é uma medida mais drástica, ao pôr fim à relação contratual, não haveria o porquê negar a via revisional que vem a viabilizar a continuação do contrato.

O princípio da função social, que é uma das principais alavancas para a implantação da nova ordem contratual de cunho social, também autoriza a entender pela aplicabilidade da hipótese de revisão contratual; pois, se o contrato deve atender a sua função social, havendo, assim, desajustes por forças estranhas às partes, não há como a justiça negar o reaproveitamento (a revisão) do contrato, estabelecendo condições (obrigações) passíveis de serem cumpridas.

Ainda justificando a possibilidade revisionista, o art. $4^{\circ}$ da Lei de Introdução ao Código Civil, estabelece que, quando a lei for omissa, o juiz decidirá o caso de acordo com a analogia, os costumes e os princípios gerais do Direito.

Assim, em face da omissão legal, nada mais justo do que aplicar-se o princípio da função social - o qual, pelo novo estatuto civilista, passou a ser regra jurídica - o que justifica ainda mais a viabilidade de revisão contratual.

Além disso, não se poderia conceber a idéia de que somente a parte beneficiária pode pleitear a revisão do contrato, conforme estabelece o art. 479, CC. Logo, se ao réu (considerando-o que seja a parte não prejudicada) foi-lhe concedida a via revisional, a mesma não poderia ser negada à parte prejudicada, sob pena de infringir o princípio constitucional da igualdade (ou isonomia).

Corroborando com esse mesmo pensamento, Bierwagen ${ }^{50}$ alude que,

quanto à resolução do contrato como único para a onerosidade excessiva, observa-se que o art. 478 não prevê, expressamente, a possibilidade de revisão por fato imprevisível e extraordinário. Entendemos que, apesar desse silêncio desse dispositivo, não há razão para excluir tal possibilidade, notadamente em face da atual sistemática imposta pelo novo Código Civil. [...] Além disso, não se pode deixar de mencionar que a resolução é medida muitas vezes não desejada pela par- 
te prejudicada pela onerosidade excessiva, que preferiria dar continuidade ao contrato desde que reajustado a níveis razoáveis. Afinal, quando as partes firmam um contrato, é de pressupor que desejem dar-lhe integral cumprimento e, assim, alcançar a finalidade almejada [...] A partir disso não é difícil concluir que o advento de um acontecimento externo, não desejado, imprevisível e extraordinário não lhes retire o desejo de concluir as prestações estabelecidas no contrato, mas apenas deixam de querê-lo pelas novas condições que se interpuseram no curso de seu cumprimento [...].

Esboçada a crítica acima, retomamse, agora, comentários em torno dos requisitos expostos no art. $478, \mathrm{CC}$. $\mathrm{O}$ primeiro requisito, que consiste na exigência de se tratar de contratos de execução continuada ou diferida, dispensa análise, tendo em vista que já foi objeto de explanação no início desse item.

O segundo requisito - onerosidade excessiva - consiste na alteração da obrigação de uma das partes durante a execução do contrato, decorrente de acontecimentos extraordinários e imprevisíveis, tornando-a um considerável sacrifício. Esse sacrifício corresponde à idéia de inviabilidade econômica na continuação do cumprimento da obrigação contratual. Veja-se um exemplo para tornar mais nítida essa idéia de sacrifício: um contrato de transporte firmado entre uma empresa de transporte e alunos residentes em determinada cidade que necessitam deslocarem-se para uma outra, em razão da queda de uma ponte existente no itinerário, exige que seja aumentado consi- deravelmente o percurso. Tal fato ocasionará, sem dúvida, maiores custos à empresa contratante, pois exigirá gasto maior com combustível, manutenção do veículo, entre outros.

Outro exemplo ainda pode ser apontado: o contrato de empreitada mista a preço fixo, ficando acertado, no memorial descritivo da obra a utilização de determinado material, vindo tal material a desaparecer do mercado, fazendo com que o empreiteiro adquira um material similar, mas com o preço com um percentual de $40 \%$ mais caro do que o especificado no memorial. Embora seja da natureza desse contrato a inalteração do preço, não resta dúvida de que essa situação gera um sacrifício ao empreiteiro, pois no cálculo do custo total não havia previsão de gastos bem elevados com o determinado material.

$\mathrm{O}$ terceiro requisito - benefício exagerado para a outra parte contratante vem a ser a vantagem patrimonial que uma parte recebe em razão do sacrifício da outra. O exemplo da queda da ponte reflete isso, pois, caso o preço do transporte não fosse reajustado, os alunos seriam beneficiados (pelo fato de serem transportados por um percurso maior) em face do sacrifício patrimonial a ser suportado pela empresa com o aumento do itinerário.

Contudo, nem sempre esse requisito se faz presente, uma vez que o fato da prestação se tornar excessivamente onerosa para uma das partes não significa que a outra seja beneficiada exageradamente. Imagine-se a seguinte situação, que é apresentada pela autora Bierwagen: ${ }^{51}$ 
um pequeno empreiteiro do interior que se compromete a construir um único imóvel, e que, no curso do contrato, vêse surpreendido pela dobra no preço do cimento na região, forçada pela presença de uma empreiteira que inicia a construção de um grande condomínio. A onerosidade excessiva experimentada pelo pequeno empreiteiro não se reflete em favor do dono da obra, que receberá o mesmo produto anteriormente contratado, não havendo dessarte, exagerada vantagem.

Com a observação feita no parágrafo anterior, entende-se que a falta de caracterização da vantagem exagerada não afasta a aplicação do disposto no art. 478, $\mathrm{CC}$; eis que não se pode negar a via revisional ou resolutiva sob o pretexto de não estar presente tal vantagem. Ademais não se pode negar solução a quem quer cumprir o contrato, mas se vê impedido por situação estranha à vontade das partes e que lhe cause um considerável prejuízo patrimonial.

E o último requisito é a ocorrência de acontecimentos extraordinários e imprevisíveis supervenientes à conclusão do contrato. Esses acontecimentos se caracterizam pela impossibilidade das partes previrem-nos no momento do ajuste.

Vistos os requisitos, há que se destacar outro ponto questionável, o qual diz respeito ao art. $479, \mathrm{CC}$, que prevê a possibilidade de revisão contratual quando o réu oferecer proposta com o fim de modificar equitativamente as condições do contrato. Desse dispositivo, lança-se a seguinte questão: oferecendo o réu proposta para modificar o contrato, poderá o juiz, considerando-a equitativa, modificar o contrato sem a concordância do autor?

Compreendendo-se que o art. 479 atribui ao juiz um poder revisionista, poderá, então, acolher a proposta do réu e modificar o contrato, obrigando o autor a cumprir o contrato nos moldes fixados pela sentença.

Oportunamente, pode-se questionar a seguinte situação: partindo-se do fato do autor ter ingressado com uma demanda pleiteando a resolução do contrato, poderá o juiz prolatar uma decisão que extrapola o pedido do autor, qual seja, a revisão e imposição de novas condições contratuais. Se agir assim, restará caracterizada uma decisão extra petita, ofendendo a matéria processual.

Contudo, não se pode compreender que ocorrerá uma irregularidade processual, pois o processo não pode (e não deve) estar desvinculado da nova ordem contratual que se estabelece. Aliás o processo é instrumento de aplicação do direito material, por isso aquele deve adaptar-se a este.

Como bem afirma Antônio Maria Iserhard: ${ }^{52}$

o juiz não é mais a boca da lei, no dizer de Montesquieu, mas o criador do direito no caso concreto. Houve um deslocamento interpretativo, do legislador para

52 ISERHARD, Antônio Maria. A Idéia de Sistema Jurídico e o Novo Código Civil: uma contribuição ao desafio hermenêutico da aplicação do direito. Anuário do Programa de PósGraduação em Direito da UNISINOS, São Leopoldo, p. 281-294, 2001. p. 9-10. 
o julgador. Para a aplicação do direito já não são suficientes os parâmetros interpretativos antropormóficos da vontade do legislador ou animista da vontade da lei, mas impõe-se uma nova visão sistemática do direito.

Dessa forma, não se pode negar, a partir da nova visão que o direito vem assumindo (visão socializante), o poder revisionista do juiz, podendo este, com o intuito de manter a relação contratual, solucionar o caso concreto estabelecendo os novos critérios a serem observados pelas partes contratantes. Aliás, essa é a interpretação mais coerente com a sistemática do novo Código, pois o contrato deve atingir sua função social - o restabelecimento do contrato em nível de equiparidade entre as partes é cumprir com sua função social (!).

Por derradeiro, faz-se uma outra ponderação, a qual diz respeito ao art. 480 , CC. Esse artigo prevê que, nos contratos unilaterais, a parte que tem o dever obrigacional poderá pleitear que sua prestação seja reduzida, ou alterado o modo de executá-la, a fim de evitar a onerosidade excessiva.

Tomando-se o aludido artigo, detecta-se que, quando se tratar de contrato unilateral de execução continuada ou diferida, resta provar a onerosidade excessiva, não necessitando a exagerada vantagem. Além disso, o artigo proporciona a revisão ou a resolução do contrato. Assim, comparando com o art. 478, $\mathrm{CC}$, percebe-se um nítido tratamento desigual, pois neste só há a previsão da resolução e há exigência da onerosidade excessiva e da extrema vantagem.

Em face de desigual tratamento, parece que não há um justo motivo para se beneficiar os contratos unilateriais; por conseguinte o artigo 480 deve ser interpretado de forma a contribuir ao entendimento de que o art. 478 não excluiu a via revisional, como também permite a sua aplicação quando restar configurada a onerosidade excessiva e não restar caracterizada a vantagem exagerada, como no exemplo dado acima.

\section{CONSIDERAÇÕES FINAIS}

A visão liberal que conduzia a vida dos contratos, como todos os ideais liberais, começam a entrar em choque em razão do processo de industrialização ocorrido no final do século XVII e, especialmente, a partir do século XIX, quando surgem conflitos que ultrapassam a esfera do indivíduo; tornando o Código Civil insuficiente para tutelar esses novos conflitos. Também as grandes guerras contribuíram para a modificação do status social. Em razão desse contexto, começam a surgir as Constituições, elencando em seu corpo textual matérias que eram exclusivas do direito privado. Além disso, aparecem as leis especiais com o fim de regulamentar as novas relações jurídicas como também retirar as que já haviam sido previstas no Código Civil, mas que se mostravam insuficientes.

Como consequiência da Constituição e das leis especiais, tem-se que o Estado passou a intervir na esfera privada, proporcionando a passagem de uma visão liberal do direito para uma visão social, onde o Estado assume o compromisso de garantir o equilíbrio nas relações efetivadas no mercado, como forma de realizar a justiça social. As- 
sim, muda-se a concepção do que é justo na relação contratual, isto é, enquanto no Estado Liberal essa emanava da liberdade das partes - a liberdade gerava a igualdade -, no Estado Social, essa está consubstanciada em proteger a parte mais fraca do vínculo, a qual é verificada caso a caso.

Essa intervenção do Estado é reconhecida como dirigismo contratual, eis que passa a dirigir, limitar a vontade das partes. Portanto, não se pode mais, hoje, falar que há a absoluta liberdade de contratar, nem mesmo em intangibilidade dos contratos.

Essa nova realidade jurídica vai levar a aplicabilidade da matéria contratual em observância aos novos princípios, quais sejam: princípio da função social, princípio da boa-fé objetiva, o princípio da probidade e o princípio da equivalência das prestações, entre outros.

Com efeito, esses princípios espelham uma nova fase, pois além de encontrarem-se expressos nessas legislações, eles impõem uma nova conduta contratual. As cláusulas gerais assumem um papel importantíssimo no Direito, pois permitem a abertura do sistema jurídico, ao viabilizar o enquadramento de um vasto número de situações de modo ilacunar e com possibilidade de ajustamento a uma solução jurídica. Ao contrário do que perfilhava no código liberal de 1916, onde, sob prevalência do casuísmo, não havia possibilidade de dar respostas aos novos conflitos.

A apresentação desses novos princípios, portanto, acarreta, sem sombra de dúvida, um desafio a todos os operado- res do Direito, pois essa nova realidade implica necessariamente numa revisão dos conceitos até então postos no direito, a fim de que, efetivamente, possam ser concretizados os ideais de justiça social impostos por esses novos paradigmas.

\section{REFERÊNCIAS}

ANDRADE, Fábio Siebeneichler. $D a$ Codificação: crônica de um conceito. Porto Alegre: Livraria do Advogado, 1997.

BARLETTA, Fabiana Rodrigues. A Revisão Contratual por Excessiva Onerosidade Superveniente à Contratação Positivada no Código de Defesa do Consumidor sob a Perspectiva CivilConstitucional. In: TEPEDINO, Gustavo (coord.) Problemas de Direito Civil-Constitucional. Rio de Janeiro: Renovar, 2000. p. 279-306.

BIERWAGEN, Mônica Yoshizato. Princípios e Regras dos contratos no Novo Código Civil. São Paulo, 2002.

CORDEIRO, António Manuel da Rocha Menezes. Da Boa-Fé no Direito Civil. Coimbra: Almedina, 1997.

ELESBÃO, Elsita Collor. Principios Informativos das Obrigações Contratuais Civis. Porto Alegre: Livraria do Advogado, 2000.

ENGISH, Karl. Introdução ao Pensamento Jurídico. 6. ed. Lisboa: Calouste, 1983.

ESPÍNDOLA, Ruy Samuel. Conceito de Princípios Constitucionais. 2. ed. São Paulo: Revista dos Tribunais, 2002.

GILISEN, John. Introdução Histórica ao Direito. 3. ed. Lisboa: Calouste, 2001. ISERHARD, Antônio Maria. A Idéia de Sistema Jurídico e o Novo Código 
Civil: uma contribuição ao desafio hermenêutico da aplicação do direito. Anuário do Programa de Pós-Graduação em Direito da UNISINOS, São Leopoldo, 2001, p. 281-294.

LARENZ, Karl. Metodologia da Ciência do Direito. 3. ed. Lisboa: Calouste, 1997.

LEWICKI, Bruno. Panorama da Boa-Fé Objetiva. In: TEPEDINO, Gustavo (Coord.) Problemas de Direito Civil-Constitucional. Rio de Janeiro: Renovar, 2000.

LISBOA, Roberto Senise. Contratos Difusos e Coletivos. São Paulo: Revista dos Tribunais, 2000.

LUDWIG, Marcos de Campos. Direito público e Direito Privado: a superação da dicotomia. In: MARTINS-COSTA, Judith (Org.) A Reconstrução do Direito Privado. São Paulo: Revista dos Tribunais, 2002.

MARINI, Celso. Algumas Considerações Importantes sobre os Contratos. Disponível em <http://www.irib.org.br/be/ be. asp> Acesso em 05 mar. 2003.

MARQUES, Cláudia Lima. Contratos no Código de Defesa do Consumidor. 2 ed. São Paulo: Revista dos Tribunais, 1995.

MARTINS-COSTA, Judith. Crise e modificação da idéia de contrato no direito brasileiro. Revista de Direito $C i$ vil, Imobiliário, Agrário e Empresarial, São Paulo, n. 59, jan./mar. 1992.

MARTINS-COSTA, Judith (Org.). A Reconstrução do Direito Privado. São Paulo: Revista dos Tribunais, 2002.
MARTINS-COSTA, Judith. A Boa-Fé no Direito Privado. São Paulo: Revista dos Tribunais, 2000.

O Direito Privado como um Sistema em Construção: as cláusulas gerais no Projeto do Código Civil brasileiro. Disponível em <http:ww.jus.com.br. Acesso em 19 fev. 2003.

MONTEIRO, Osvaldo de Carvalho. Cláusula Rebus Sic Stantibus. Revista Forense. Rio de Janeiro, v.49, n. 476, p. 242-255, abr. 1943.

NALIN, Paulo. Do Contrato: conceito pós-moderno. Curitiba: Juruá, 2001.

NOVAIS, Aline Arquette Leite. Breves Reflexões sobre a Eficácia atual da Boa-Fé Objetiva no Ordenamento Jurídico Brasileiro. In TEPEDINO, Gustavo (Coord.). Problemas de Direito Civil. Rio de Janeiro: Renovar, 2001.

SILVA, Clóvis V. do Couto e. A Obrigação como Processo. São Paulo: Bushatsky, 1976.

SUNFELD, Carlos Ari. In: ESPÍNDOLA, Ruy Samuel. Conceitos e Princípios Constitucionais. 2.ed. São Paulo: Revista dos Tribunais, 2002.

TEPEDINO, Gustavo. Temas de Direito Civil. 2. ed. Rio de Janeiro: Renovar, 2001 .

TEPEDINO, Maria Celina B. M. A Caminho de um Direito Civil Constitucional. Revista de Direito Civil, Imobiliário, Agrário e Empresarial, São Paulo, n. 65, jul./set. 1993. 